\title{
Diurnal variations in blood sugar concentration in ruminating calves
}

\author{
By T. R. PRESTON AND R. D. NDUMBE \\ Rowett Research Institute, Bucksburn, Aberdeen \\ (Received 19 October 1960-Revised 30 December 1960)
}

Most workers consider that there is little diurnal variation in blood sugar concentration in ruminants and that feeding has no significant effect on this characteristic (Schuhecker, I925; Richter, I928; Hodgson, Riddell \& Hughes, I932; Magee, I932; Allcroft \& Strand, 1933; Kennedy, Anderson, Bechdel \& Shigley, r939; Sampson \& Boley, 1940; McCandless \& Dye, 1950; Reid, 1950; Barhydt \& Dye, 1957). In one experiment, however, Allcroft (1933) noted a diurnal variation in blood sugar concentration in lactating cows although the effect was not observed in dry cows.

In calves reared by the 'early-weaning' method (Preston, 1956) the onset of rumen function is accelerated by replacing the standard diet of the young calf, namely milk or a milk replacement, with a solid concentrate feed containing a high proportion of starch and dextrin. The mode of utilization of this concentrate in the ruminating calf is of interest since ingested starch may escape fermentation in the rumen and, after hydrolysis in the intestine, may influence the level of reducing sugar in the blood. The study described here is concerned with the effect of concentrates, cow's whole milk and dried grass on the level of reducing sugar in the venous blood of ruminating calves.

\section{EXPERIMENTAL}

Animals. Eleven female Ayrshire calves were used at ages varying from to to I6 weeks. They had been weaned from liquid feeding at 3 weeks of age, and thereafter, before they received the experimental diets, were given a dry concentrate mixture ad lib., according to the procedure outlined by Preston (1956). All calves were ruminating before weaning.

Experimental diets. Three diets were studied: (I) An 'early-weaning' concentrate mixture, (2) cow's whole milk, (3) dried grass. The composition of the concentrate was: flaked maize $224 \mathrm{lb}$, bruised oats $\mathrm{I} 68 \mathrm{lb}$, molassine meal (containing $75 \%$ molasses and $25 \%$ sphagnum moss, Molassine Co. Ltd, Greenwich, London, S.E. ro) $84 \mathrm{lb}$, extracted, decorticated groundnut meal $84 \mathrm{lb}$, limestone $3 \mathrm{lb}$., bone meal $3 \mathrm{lb}$, chlortetracycline $4.5 \mathrm{~g}$, vitamin A 1000000 i.u., vitamin D 250000 i.u. The dried grass had been ground through the $\frac{1}{2}$ in. screen of a hammer mill; it contained $\mathrm{I} 6 \%$ crude protein on a dry-matter basis. Each diet was given to five different calves.

Feeding. Each calf was given the experimental diet for a preliminary period of at least 14 days before blood samples were taken. The air-dry concentrate mixture was given at the daily rate of $8 \%$ of the metabolic body size $\left(0.08 \times \mathrm{kg}\right.$ body-weight $\left.{ }^{0.74}\right)$ at 
the beginning of the preliminary period. Sufficient milk and grass were given to provide approximately the same intake of digestible energy per unit of metabolic body size as the concentrate diet. Feeding was twice daily at 8.10 a.m. and 7.10 p.m. except in one experiment with the concentrate diet, when one calf was given its evening feed at 4.I0 p.m. instead of 7.10 p.m. The same calf was studied on a second occasion when feeding was at the normal times of 8.10 a.m. and 7.I0 p.m.

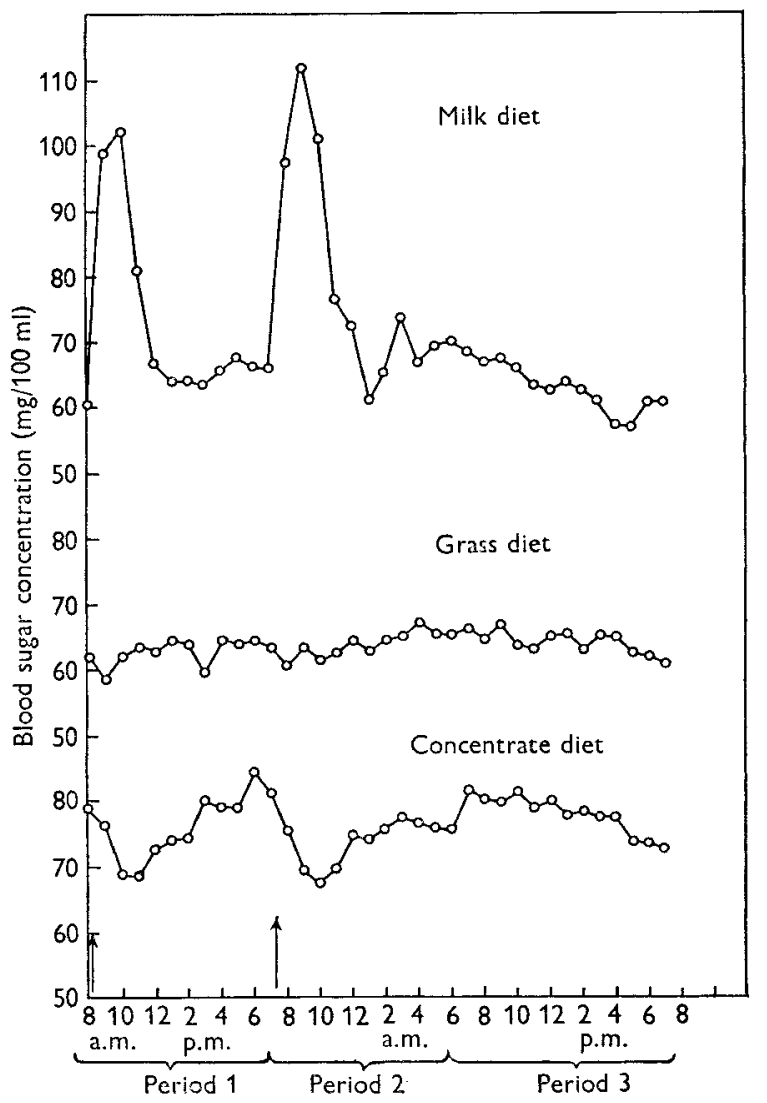

Fig. I. Mean concentrations of reducing sugar in the blood of I 2-week-old calves given diets of milk, dried grass or a concentrate (arrows show times of feeding). The standard errors of means for periods $I, 2$ and 3 respectively were $\pm 6 \cdot 6, \pm 8 \cdot 5$ and $\pm I \cdot 9$ with milk, $\pm 2 \cdot 6, \pm 2 \cdot 0$ and $\pm \mathrm{r} \cdot 6$ with grass, and $\pm 3.5, \pm 3 . \mathrm{I}$ and $\pm \mathrm{I} .5$ with the concentrate.

Sampling. At 6 a.m. on the morning on which the first blood samples were to be taken, a Polythene catheter $20 \mathrm{~cm}$ long and of $0.2 \mathrm{~cm}$ internal diameter was inserted in the jugular vein of the calf and closed by a nylon stilette of the same length, the external diameter of which equalled the internal bore of the catheter. Blood samples were withdrawn by removing the stilette and applying a syringe to the end of the catheter; heparin was used as anticoagulant. Three series of samples were taken at hourly intervals in three periods: period I from 8 a.m. to 7 p.m. on the ist day, the calves being fed at 8.10 a.m.; period 2 from 7 p.m. on that day to 6 a.m. on the following day, 
the calves being fed at $7 \cdot 10$ p.m.; period 3 from 6 a.m. to 7 p.m. on the 2 nd day, when no feed was given.

The reducing sugar in blood was determined by the method of Nelson (I944) with the copper reagent of Somogyi (1952).

\section{RESULTS}

The mean values for blood sugar concentration in calves given the different diets are shown in Fig. I. In periods $I$ and 2 with milk feeding there was a steep rise to a maximum value $2 \mathrm{~h}$ after feeding followed by an equally steep fall towards the initial level, which was reached about $5 \mathrm{~h}$ after feeding. These effects were statistically

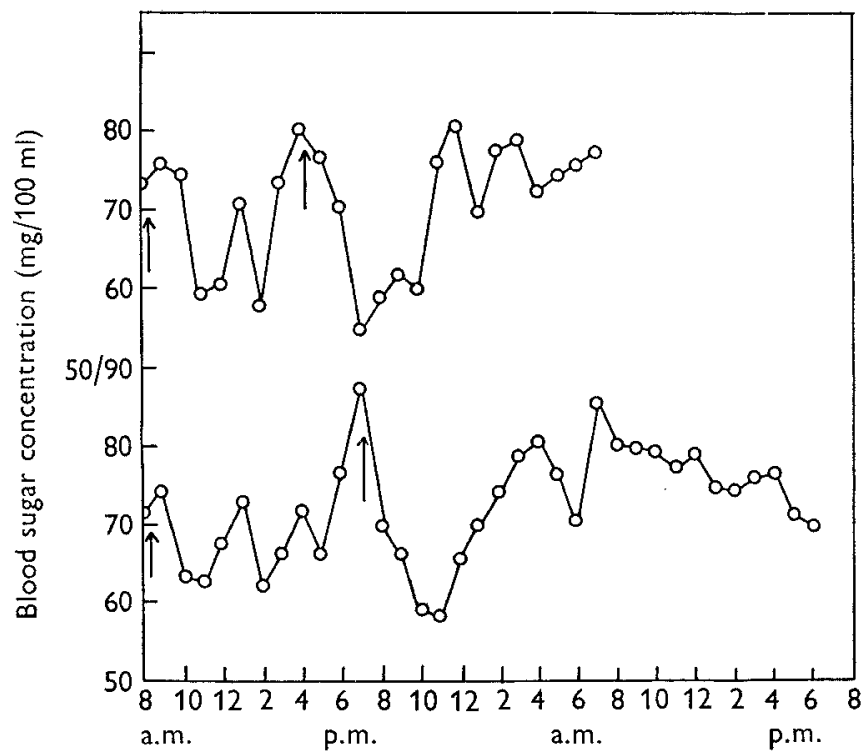

Fig. 2. Concentration of reducing sugar in the blood of calf no. 6or given a concentrate at 8.10 a.m. and 4.10 p.m. in one experiment (upper line) and at 8.10 a.m. and 7.10 p.m. in a subsequent experiment (lower line) (arrows indicate times of feeding).

significant $(P<0.01)$. During period 3 , in which the animals were kept fasting, the values were stable for the first $4 \mathrm{~h}$ and then fell gradually for the remainder of the period, the effect being significant $(P<0.01)$. The pattern thus differed markedly from that of the first two periods.

With grass the values in periods $I$ and 2 fluctuated randomly about a mean of $63 \mathrm{mg} / \mathrm{I} 00 \mathrm{ml}$, but the pattern in period 3 was again a steady decline similar to that with milk. This decline in period 3 was significant $(P<0.05)$.

With the concentrate diet there were changes in periods $I$ and 2 consisting of a sharp fall to a minimum value $3 \mathrm{~h}$ after feeding followed by a gradual rise to values similar to those at the beginning. In period 3 there was a decline similar to that with milk and grass but the value reached was not as low as that attained in periods $I$ and 2. The changes in all three periods were significant $(P<0.01)$. 
One calf received its evening feed during one experiment with the concentrate at 4.10 p.m. and in a second experiment at 7.10 p.m. (see Fig. 2). When the feed was given at 4.10 p.m. the blood sugar reached a minimum value at 7 p.m., but when the giving of the feed was delayed until 7.10 p.m. the maximum depression in blood sugar was not reached until i I p.m. This observation affords corroborative evidence that the depression in blood sugar level with concentrate feeding is related to eating.

\section{DISCUSSION}

In this experiment the hyperglycaemia after the intake of milk was in agreement with the findings of many other workers (Kennedy et al. 1939; McCandless \& Dye, 1950; Dye \& Orsini, 1952; Jarrett \& Potter, 1952; Barhydt \& Dye, r957). It is known (Comline \& Titchen, I95I) that when milk is given to the young calf it passes in the main directly to the abomasum, by-passing the rumen through the oesophageal groove. In the abomasum and also in the intestine lactose is converted into glucose and galactose, the absorption of which is rapid. Thus a peak value for blood glucose within $\mathrm{I}-\mathbf{2} \mathrm{h}$ of feeding with milk is to be expected. Presumably part of this increase in circulating reducing substances may be due to galactose.

No one appears to have studied blood sugar concentration in I2-week-old calves given dried grass, but certain workers who have given hay to calves (Barhydt $\&$ Dye, 1957) and sheep (Reid, 1950) have reported that it had no effect on the blood sugar concentration - a finding which is in line with our own observations.

The most significant feature of our findings in I2-week-old calves was undoubtedly the significant, although temporary, depression in blood sugar concentration after the intake of concentrates. As far as we are aware this finding has not previously been reported. Though we are not yet in a position to comment in detail on the reason for this depression, it is worth noting that, when the blood sugar concentration was lowest, rumen fermentation, as measured by concentration of steam-volatile fatty acids, was probably at its peak (Preston \& Dinda, unpublished data).

In general, the proportion of propionic acid in the steam-volatile fatty-acid mixture in rumen liquor increases as the proportion of concentrates in the diet increases (Balch \& Rowland, 1957). On the other hand, there are reports that under certain conditions and particularly at low rumen $\mathrm{pH}$ (R. L. Reid, I960, personal communication) a diet composed exclusively of concentrates, and having no roughage, produces in the rumen a mixture of volatile fatty acids which contains abnormally low proportions of propionic acid. Moreover, the fermentation of glucose and of endogenous polysaccharide by certain rumen ciliates is known to produce mainly butyric, acetic and lactic acid with only traces of propionic acid (Heald \& Oxford, r953; Akkada, Hobson \& Howard, 1959).

The metabolism of a volatile fatty-acid mixture low in propionic acid, by way of the tricarboxylic-acid cycle, will thus require additional sources of glucose to compensate for the lack of propionic acid, which is the only volatile fatty acid immediately glucogenic. This requirement for additional glucose might well be reflected in a temporary depression in blood sugar at a time coincident with peak rumen fermentation. 
The rise in blood sugar from the $4^{\text {th }}$ to the $\mathrm{I} 2$ th $\mathrm{h}$ after the intake of concentrate could be attributed to hydrolysis in the intestine of dietary starch that had escaped fermentation in the rumen. The maximum value was reached 8-I2 h after the intake of food.

The gradual and significant fall in blood sugar concentration when the animals were not fed (with all diets in period 3 of the experiments) has been reported by other workers (Magee, I932; Reid, 1950) as the normal response to a fast of $24-3^{6} \mathrm{~h}$.

\section{SUMMARY}

I. Diurnal variations in the concentration of reducing sugar in venous blood were studied in groups of five I2-week-old calves given diets of either whole milk, concentrates or dried grass; the calves had been weaned at 3 weeks of age and rumination was well established.

2. With a milk diet there was a sharp rise immediately after feeding followed by an equally rapid fall to prefeeding levels.

3. With dried grass there were no changes due to feeding.

4. With concentrates there was a depression to a minimum value $3 \mathrm{~h}$ after feeding and then a gradual rise to a maximum value 8-I $2 \mathrm{~h}$ after feeding.

5. When no food was given the pattern, similar with all three diets, was a steady fall in blood-sugar values.

We are grateful to Mr I. Macdonald for statistical analysis of the results and to Mr F. G. Whitelaw, Miss E. B. Charleson and Miss A. Mailey for assistance with the analytical techniques.

\section{REFERENCES}

Akkada, A. A. R., Hobson, P. N. \& Howard, B. H. (1959). Biochem. 7. 73, 44 P.

Allcroft, W. M. (1933). Biochem. F. 27, 1820 .

Allcroft, W. M. \& Strand, R. (1933). Biochem. F. 27, 512.

Balch, D. A. \& Rowland, S. J. (1957). Brit. F. Nutr. 11, 288.

Barhydt, J. B. \& Dye, J. A. (1957). Cornell Vet. 47, 76.

Comline, R. S. \& Titchen, D. A. (195I). F. Physiol. r15, zio.

Dye, J. A. \& Orsini, D. (1952). Fed. Proc. I1, 39.

Heald, P. J. \& Oxford, A. E. (I953). Biochem. F. 53, 506.

Hodgson, R. E., Riddell, W. H. \& Hughes, J. S. (1932). F. agric. Res. 44, 357.

Jarrett, I. G. \& Potter, B. J. (1952). Aust. F. exp. Biol. med. Sci. 30, 207.

Kennedy, W. L., Anderson, A. K., Bechdel, S. I. \& Shigley, J. F. (1939). F. Dairy Sci. $22,25$.

Magee, H. E. (1932). F. $\operatorname{exp.~Biol.~9,~} 409$.

McCandless, E. L. \& Dye, J. A. (1950). Amer. F. Physiol. 162, 434.

Nelson, N. (1944). F. biol. Chem. 153, 375 .

Preston, T. R. (1956). Proc. Brit. Soc. Anim. Prod. p. 67.

Reid, R. L. (1950). Aust. F. agric. Res. 1, 182.

Richter, A. (1928). Biochem. Z. 194, 376.

Sampson, J. \& Boley, L. E. (1940). F. Amer. vet. med. Ass. 96, 480.

Schuhecker, K. (1925). Biochem. Z. 156, 353.

Somogyi, M. (1952). F. biol. Chem. r95, 19. 